\title{
Effect of pregnancy and embryonic mortality on milk production in dromedary camels (Camelus dromedarius)
}

\author{
P. Nagy, ${ }^{* 1}$ V. Faigl,† J. Reiczigel,‡ and J. Juhasz* \\ *Emirates Industries for Camel Milk \& Products, Farm \& Veterinary Section, PO Box 294236, Dubai, United Arab Emirates \\ †Department and Clinic of Reproduction, and \\ †Department of Biomathematics and Informatics, Faculty of Veterinary Science, Szent Istvan University, Budapest, Hungary H-1078
}

\section{ABSTRACT}

The main objective of the present study was to compare milk production in pregnant versus nonpregnant dromedary camels. In addition, we described the effect of embryonic mortality on lactation and measured serum progesterone levels until d 60 to 90 of gestation. Twenty-five multiparous camels were selected in midlactation for 2 studies in consecutive years. Camels were mated naturally when the size of the dominant follicle reached 1.2 to $1.5 \mathrm{~cm}$. Pregnancy was diagnosed by ultrasonography and progesterone determination. In the first experiment (Exp 1), 8 of 11 animals conceived at $284 \pm 21.5 \mathrm{~d}$ postpartum. Three pregnant dromedaries were given $\mathrm{PGF}_{2 \alpha}$ to induce luteolysis and pregnancy loss on d 62 and spontaneous embryonic loss was detected in 2 camels (on d 27 and 60). Animals were allotted to 3 groups retrospectively: nonpregnant camels (group $1, \mathrm{n}=4$ ), pregnant camels (group $2 ; \mathrm{n}=3$ ), and camels with embryonic loss after d 55 (group 3; n $=4)$. In the second study (Exp 2), 14 dromedaries were mated during midlactation. Seven of them failed to conceive (group 1) and 7 became pregnant (group 2). No embryonic loss was detected in Exp 2. Turning points in milk production were identified by change point analysis. In nonpregnant dromedaries (group 1), milk decreased slowly over time without significant change point. In pregnant camels (group 2), a gradual decline until 4 wk after mating was followed by a sudden drop, and the change point model resulted in one breakpoint at $\mathrm{d} 28 \pm 7$ and $35 \pm 3$ of gestation in Exp 1 and Exp 2, respectively. In camels with embryonic mortality (group 3, Exp 1), milk yield started to decline similarly as in pregnant animals, but milk production increased gradually after embryonic loss and reached similar levels as in their nonpregnant herdmates. Change point analysis for group 3 resulted in 2 turning points at $30 \pm$ 4 and $48 \pm 4 \mathrm{~d}$ after conception. Mean length of lacta-

Received June 30, 2014.

Accepted October 13, 2014.

${ }^{1}$ Corresponding author: peter@camelicious.ae tion was shorter by $230(34.2 \%)$ and by $249 \mathrm{~d}(37.6 \%)$ and mean total lactation production was decreased by $1,532(31.6 \%)$ and $2,151 \mathrm{~kg}(44.3 \%)$ in pregnant compared with nonpregnant camels in Exp 1 and Exp 2, respectively. We concluded that the calving interval can be shortened by mating during midlactation. However, pregnancy has a strong negative effect on milk production as dromedaries stop lactating by the fourth month of gestation. Following embryonic mortality within 3 mo of conception, milk production is restored.

Key words: dromedary camel, pregnancy, lactation, embryonic mortality, progesterone

\section{INTRODUCTION}

Camel milk has an important role in the food security and rural economy of arid zones of north and east Africa, central Asia, and the Indian subcontinent. At the same time, camel milk consumption is increasing among the urban population throughout the region, including the Middle East. According to FAO statistics, total camel milk production has increased by 2.6 fold from the 1960s, reaching 1.7 million tonnes per year by 2009. In some regions, such as the horn of Africa, $10 \%$ of the milk is derived from dromedaries (Faye and Bonnet, 2012). In addition, interest is growing in camel milk among specific consumer groups in North America and Europe due to its potential medical benefits ( $\mathrm{Al}$ Haj and Al Kanhal, 2010).

Intensification of camel milk production started in the last decade, coinciding with increasing demand (Juhasz and Nagy, 2012; Nagy et al., 2013b). However, the fast growth in production is hampered by the low reproductive efficiency of the species. The time of first parturition in camels is usually above $5 \mathrm{yr}$ of age, the gestation period is long $(>370 \mathrm{~d})$, and the calving interval of dairy animals exceeds 2 yr (Tibary and Anouassi, 1997). In a recent survey including 49 lactating dromedaries, we observed $834 \pm 16.1$ (mean \pm SEM) and $362 \pm 14.6 \mathrm{~d}$ for the calving interval and dry period, respectively (Nagy and Juhasz, 2010).

The extended calving interval is not only the result of a long gestation, but also that of the long milking 
period and management during lactation (Nagy et al., 2013b). In most of the management systems, camels are kept together with their calves for more than a year, are considered to be in lactation anestrus during milking, and are bred only after the complete weaning of the calf (Tibary and Anouassi, 1997). In our farm, we also keep the calves in adjacent paddocks close to their dams throughout lactation and start mating after $400 \mathrm{~d}$ of lactation (Juhasz and Nagy, 2012). This practice results in a long calving interval (24 to $34 \mathrm{mo}$ ). According to field observations of herdsmen and pastoral people, the presence of the calf is essential for maintaining milk production and pregnant camels stop lactating. In a previous study (Nagy et al., 2005), we showed that regular follicular wave development and spontaneous ovulation occur in lactating dromedaries. Therefore, it is likely that ovarian activity is not a limiting factor for conception during midlactation under intensive management with improved nutrition and good body condition. However, no data are available concerning the effect of pregnancy on milk yield in this species. Such data would be of vital importance to decrease the long calving interval in lactating dromedaries.

The phenomenon of decreasing milk production during pregnancy has already been demonstrated in several species, including cow (Olori et al., 1997; Bormann et al., 2002), goat (Knight and Wilde, 1988; Salama et al., 2005), sheep (Faigl et al., 2011), and buffalo (Khan et al., 2011, 2012). However, a difference exists among species in their lactation response to pregnancy. In cows, the negative effect of gestation is significant but marginal and can only be observed in later stage of gestation (Sharma et al., 1990; Roche, 2003). In contrast, small ruminants and buffalo have a sharper decline in milk production after conception. The aims of the present study were to (1) evaluate the effect of breeding in dromedary camels during midlactation; (2) compare milk production pattern in pregnant versus nonpregnant animals; (3) describe the effect of embryonic mortality on lactation; and (4) assess serum progesterone changes until d 60 to 90 of gestation.

\section{MATERIALS AND METHODS}

\section{Animals and Management of the Farm}

The study was conducted during 2 consecutive breeding seasons in 2009 and 2010 at the premises of Emirates Industries for Camel Milk \& Products, the world's first large-scale camel dairy farm in Dubai, United Arab Emirates. Lactating, multiparous dromedary camels were between 8 to $17 \mathrm{yr}$ of age, in moderate to good body condition (BCS $\geq 3$ on the scale of 1 to
5; Tibary and Anouassi, 1997) with BW ranging from 550 to $650 \mathrm{~kg}$. Females were kept together in open paddocks in groups of 24 animals; they were at the same stage of lactation. Animals received a daily ration of $4.2 \mathrm{~kg}$ of wheat bran and $6 \mathrm{~kg}$ of alfalfa hay distributed in 4 portions throughout the day. Mineral blocks and water were available ad libitum. Male dromedaries of known fertility were kept in individual paddocks approximately $100 \mathrm{~m}$ from the milking animals. Further details of management have been described in previous papers (Juhasz and Nagy, 2012; Nagy et al., 2013b).

\section{Experimental Design}

In the first experiment (Exp 1), 11 lactating dromedaries kept in the same paddock were selected in February 2009 at the peak of the breeding season. Camels were at $270 \pm 12.7 \mathrm{~d}$ (mean \pm SEM) postpartum, which is the middle of lactation in this species (Nagy et al., 2013b). Ovarian activity was monitored with transrectal examination and ultrasonography (Aloka 500, $5 \mathrm{MHz}$ linear array, Hitachi Aloka Medical Ltd., Tokyo, Japan) at 2- to 3-d intervals. Camels were mated naturally with 1 of 8 fertile bulls from the breeding program when the size of the dominant follicle reached 1.2 to $1.5 \mathrm{~cm}$. Pregnancy was diagnosed by ultrasonography on 14, 28, and $42 \mathrm{~d}$ after mating. Animals that did not become pregnant were mated again during subsequent follicular wave cycles. Three of 7 pregnant dromedaries were given $\mathrm{PGF}_{2 \alpha}$ (cloprostenol, $500 \mu \mathrm{g}$ / animal, i.m.; Estrumate, Schering-Plough, Union, NJ) to induce luteolysis and embryonic mortality on d 62 of gestation. In addition, 1 camel had spontaneous embryonic mortality on d 60 of gestation. Animals were divided into 3 groups retrospectively based on their breeding performance. Nonpregnant camels (group 1, $\mathrm{n}=4$ ) were mated but did not conceive or 1 camel had embryonic mortality before d 28. Pregnant camels (group $2, \mathrm{n}=3$ ) conceived and carried the pregnancy to term. Camels with embryonic mortality (group 3, $\mathrm{n}$ $=4$ ) conceived but underwent spontaneous or induced embryonic mortality after $55 \mathrm{~d}$ of gestation.

In the second experiment (Exp 2), 14 lactating camels were selected in January 2010. The animals were kept in the same paddock and were at $250 \pm 8.8 \mathrm{~d}$ postpartum. Reproductive management, breeding, and pregnancy diagnosis were carried out the same way as in the previous year. Camels were divided into 2 groups based on their pregnancy status. Nonpregnant camels (group $1, \mathrm{n}=7$ ) were mated but did not become pregnant. Pregnant camels (group 2, $\mathrm{n}=7$ ) conceived after natural mating and carried the pregnancy to term or aborted after the end of lactation. 


\section{Milking of Dromedaries, Milk Data Recording, and Production Parameters}

Dromedaries were milked 2 times a day with an automatic system in a $2 \times 12$ herringbone milking parlor with 9 and $15 \mathrm{~h}$ of difference between morning and afternoon milking sessions. Calves were kept in adjacent paddock, close to their dams, throughout lactation. This partial separation allowed constant visual and olfactory contact. In addition, calves were together with their dam for 30 min after each milking. Details of the parlor and milking routine have been described elsewhere (Nagy et al., 2013a). Milk yield (kg) of individual dromedaries was measured during each milking with an International Committee for Animal Recording-approved milk meter. Data were collected by herd management software. For each animal, the following production parameters were recorded: daily milk yield $(\mathrm{kg} / \mathrm{d})$, total milk per lactation $(\mathrm{kg})$, average daily yield per lactation $(\mathrm{kg} / \mathrm{d})$, length of lactation (d), and time from conception to drying off (d).

\section{Blood Sampling and Progesterone Assay}

Blood samples for progesterone determination were collected by jugular venipuncture into tubes without any preservative (BD Vacutainer, Plymouth, UK) to confirm pregnancy and embryonic mortality. Tubes were centrifuged $(4,000 \mathrm{rpm}, 10 \mathrm{~min}$, at room temperature) immediately after collection and the serum was stored at $-20{ }^{\circ} \mathrm{C}$ until assayed for progesterone. In Exp 1 , samples were taken from pregnant animals (group 2 and $3, \mathrm{n}=7$ ) from d 15 until 60 at 5 -d intervals. In addition, blood was taken from group 3 camels $(\mathrm{n}=4)$ 1 and $3 \mathrm{~d}$ after $\mathrm{PGF}_{2 \alpha}$ administration or spontaneous embryonic mortality to confirm luteolysis. In Exp 2, in view of preliminary results of the previous year, sample collection for progesterone from pregnant dromedaries (group 2, n = 7) was extended from d 15 until 90 of gestation at 5-d intervals. Progesterone concentration was determined in duplicates with a commercially available ELISA assay (Ridgeway Science, Alvington, UK; Nagy et al., 2005). Progesterone dissolved in camel sera was used as standard. Intra- and interassay coefficients of variation for controls $(3.5-4.0 \mathrm{ng} / \mathrm{mL})$ were 7.5 and $12.4 \%$, respectively. Samples from the same animal were determined in the same assay. Values above $1 \mathrm{ng} /$ $\mathrm{mL}(3.18 \mathrm{nmol} / \mathrm{L})$ were considered as the sign of luteal activity and pregnancy.

\section{Statistical Analysis}

Day 0 was defined as the day of conception. In nonpregnant animals (group 1), the date of first mating was considered as d 0. Data from Exp 1 (2009) and Exp 2 (2010) were analyzed separately. Daily milk yield was evaluated by 1-wk periods from $4 \mathrm{wk}(28 \mathrm{~d})$ before until 13 wk (90 d) after conception. The effect of pregnancy on milk production was tested with ANOVA using group and period as main factors in the model. Tukey post hoc test was applied to define difference between groups in Exp 1. Change points in milk production of groups were identified by fitting broken lines to data according to Muggeo (2003) using the package "segmented" in R 3.0.2 statistical software (R Core Team, 2013). For this analysis, we used the time interval from 4 wk before to $10 \mathrm{wk}$ after conception. Lactation production data (length, total production, average daily yield) between nonpregnant and pregnant dromedaries were compared with $t$-test. In Exp 1, camels with embryonic mortality (group 3) were classified as nonpregnant for this comparison. Effect of time on serum progesterone concentration in pregnant camels was tested with linear regression. Difference at $P<0.05$ was considered significant.

\section{RESULTS}

\section{Breeding Performance: Conceptions and Follow-Up of Pregnancies}

Details of breeding performance during both seasons are presented in Table 1. In Exp 1, all 11 camels had regular ovarian activity and were mated during 21 follicular wave cycles that resulted in 8 pregnancies $(38.1 \%$ per cycle conception rate). Camels conceived at $284 \pm$ 21.5 d postpartum (March $11 \pm 6.8$ d). Embryonic mortality was detected in 2 dromedaries: 1 on d 27 and 1 on d 60 of gestation. In the analysis, the first camel was classified as nonpregnant (group 1), whereas the second one was evaluated together with prostaglandin-treated animals (group 3). Pregnant dromedaries (group 2, n = 3) delivered a healthy calf at $377 \pm 8.9$ days of gestation.

In Exp 2, 14 dromedaries were mated during 19 follicular wave cycles resulting in 7 pregnancies $(36.8 \%$ per cycle conception rate; Table 1). Camels conceived at $267 \pm 10.3 \mathrm{~d}$ postpartum (January $24 \pm 3.3 \mathrm{~d}$ ). No embryonic mortality was detected in this study, but 1 dromedary aborted a fetus on $315 \mathrm{~d}$ of gestation after the end of lactation. Six of 7 pregnant dromedaries (group 2) delivered healthy calf at $390 \pm 1.7 \mathrm{~d}$ of gestation.

\section{Serum Progesterone in Pregnant Camels}

In Exp 1, mean serum progesterone concentration was $4.6 \pm 0.28 \mathrm{ng} / \mathrm{mL}$ between $\mathrm{d} 15$ to 60 in pregnant 
Table 1. Breeding performance of dromedaries in experiments 1 (2009) and 2 (2010)

\begin{tabular}{lcccc}
\hline $\begin{array}{l}\text { Number of } \\
\text { natural matings } \\
\text { (per camel) }\end{array}$ & $\begin{array}{c}\text { Number of } \\
\text { nonpregnant } \\
\text { camels }\end{array}$ & $\begin{array}{c}\text { Number of } \\
\text { pregnant } \\
\text { camels }\end{array}$ & $\begin{array}{c}\text { Total number } \\
\text { of camels }\end{array}$ & $\begin{array}{c}\text { Total number } \\
\text { of matings }\end{array}$ \\
\hline Experiment 1 & $1^{1}$ & 4 & 5 & 5 \\
1 & 1 & 2 & 3 & 6 \\
2 & 2 & 0 & 2 & 6 \\
3 & 0 & 1 & 1 & 4 \\
4 & 4 & $7^{2}$ & 11 & $21(38.1 \%)$ \\
Total & 4 & 5 & 9 & 9 \\
Experiment 2 & 3 & 2 & 5 & 10 \\
1 & 7 & $7^{3}$ & 14 & $19(36.8 \%)$ \\
2 & & & &
\end{tabular}

${ }^{1}$ One camel had embryonic mortality on d 27.

${ }^{2}$ Three camels were given $\mathrm{PGF}_{2 \alpha}$ on $\mathrm{d} 62$ and 1 animal had spontaneous embryonic mortality on $\mathrm{d} 60$.

${ }^{3}$ One camel aborted on d 315 of gestation after the end of lactation.

camels (groups 2 and $3, \mathrm{n}=7$ ). Serum progesterone levels decreased during the observation period with a slope of $-0.0197 \pm 0.02 \mathrm{ng} / \mathrm{mL}$ per day, although this decline was not significant $(P=0.324$; Figure 1$)$. In $\mathrm{PGF}_{2 \alpha}$-treated camels, serum progesterone concentration decreased below $1 \mathrm{ng} / \mathrm{mL}$ within $1 \mathrm{~d}$ after treatment.

In Exp 2, mean serum progesterone concentration was $5.2 \pm 0.17 \mathrm{ng} / \mathrm{mL}$ between $\mathrm{d} 15$ to 90 in pregnant camels. Progesterone levels decreased significantly over time with a slope of $-0.0317 \pm 0.007 \mathrm{ng} / \mathrm{mL}$ per day $(P<0.001 ;$ Figure 1).

\section{Daily Milk Yield and Total Lactation Production}

In both studies, a significant effect of period $(P<$ $0.001)$, group $(P<0.001)$, and group $\times$ period interaction $(P<0.001)$ was detected on average daily milk yield from 4 wk $(28 \mathrm{~d})$ before until 13 wk (90 d) after conception. In Exp 1, post hoc test revealed significant difference between group 2 (pregnant camels, $7.1 \pm 0.16 \mathrm{~kg} / \mathrm{d}$ ) versus group 1 (nonpregnant, $8.1 \pm$ $0.09 \mathrm{~kg} / \mathrm{d} ; P<0.001$ ) and group 3 (embryonic mortality, $8.3 \pm 0.10 \mathrm{~kg} / \mathrm{d} ; P<0.001)$. Albeit, average daily milk yield was not different between group 1 and group 3 camels $(P=0.448)$.

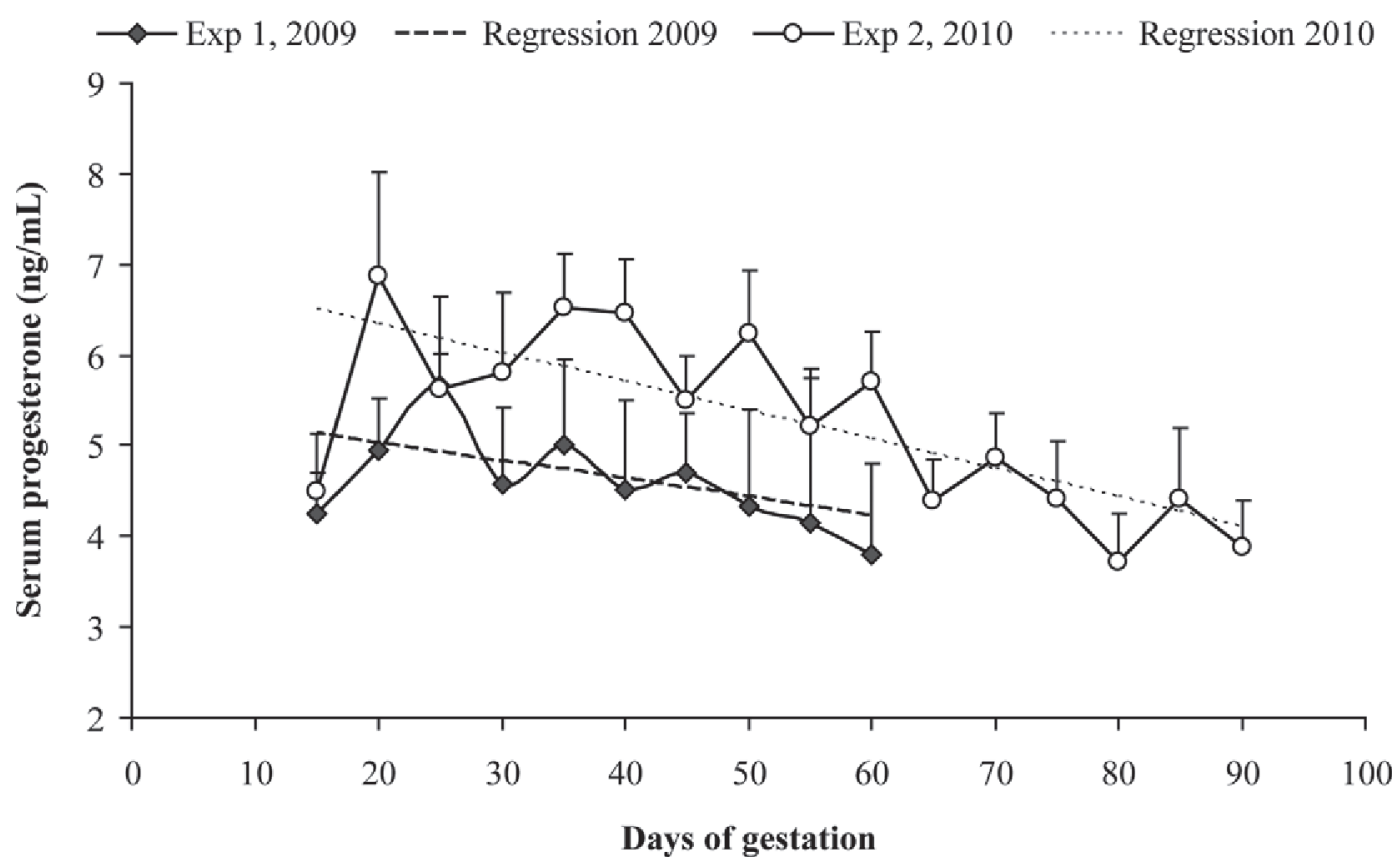

Figure 1. Changes in mean serum progesterone concentration $(\mathrm{ng} / \mathrm{mL})$ in pregnant dromedaries from 15 to 60 and to $90 \mathrm{~d}$ of gestation in 2009 and in 2010. Error bars indicate SEM. 
In Exp 1, average milk production of nonpregnant dromedaries (group 1) decreased slowly over time from $9.4 \pm 0.36 \mathrm{~kg} / \mathrm{d} 4$ wk before mating to $7.64 \pm 0.50 \mathrm{~kg} / \mathrm{d}$ by the ninth week after mating $(18 \%$ decrease; Figure 2 ). In pregnant camels (group 2), the gradual decrease in milk yield until 4 wk after conception was followed by a drop from $8.4 \pm 0.58$ to $5.4 \pm 0.29 \mathrm{~kg} / \mathrm{d}$ by the ninth week of gestation ( $40 \%$ decrease from the time of conception). Then, milk production continued to drop until camels dried off at $115 \pm 17.9 \mathrm{~d}$ of gestation (Figure 2). In group 3, daily milk yield showed a similar, decreasing pattern as in group 2. Average daily yield fell from $9.0 \pm 0.42 \mathrm{~kg} / \mathrm{d}$ during the fourth week after conception to $6.5 \pm 0.21 \mathrm{~kg} / \mathrm{d}$ by the ninth week (32\% decrease from conception). Following embryonic mortality on d 62 , milk production started to increase gradually and reached similar levels as in nonpregnant animals (Figure 2).

The change point analysis confirmed our observations. No significant change point could be identified $(P=0.722)$ in group 1 (nonpregnant) camels. The slope of the lactation curve was $-0.024 \pm 0.003 \mathrm{~kg} / \mathrm{d}$ (Figure 3a). In group 2 (pregnant camels), the change point model resulted in a breakpoint $28 \pm 7 \mathrm{~d}$ after conception. Slope of the lactation curve changed from $-0.009 \pm 0.013$ to $-0.094 \pm 0.026 \mathrm{~kg} / \mathrm{d}$ at that point $(P<0.001$, Figure $3 \mathrm{~b})$. Assuming a second change point did not result in any improvement $(P=0.881)$. In group 3 (embryonic mortality), the model with 2 change points proved to be the best $(P=0.012)$. The estimated change points were at $30 \pm 4$ and $48 \pm 4 \mathrm{~d}$ after conception. Slope changed from $-0.011 \pm 0.007$ to $-0.144 \pm 0.043 \mathrm{~kg} / \mathrm{d}$ at the first point, and to 0.003 $\pm 0.060 \mathrm{~kg} / \mathrm{d}$ at the second point (Figure 3c).

In Exp 1, mean length of lactation of pregnant camels (group 2, n $=3$ ) was shorter by $230 \mathrm{~d}$ (673 and $443 \mathrm{~d}$, $34.2 \%, P<0.001)$ and mean total lactation production was reduced by $1,532 \mathrm{~kg}(4,852$ and $3,320 \mathrm{~kg}, 31.6 \%, P$ $<0.001)$ compared with nonpregnant animals including those with embryonic mortality (groups 1 and 3, $\mathrm{n}=8$; Figure 4). Summary of lactation parameters in non-pregnant and pregnant camels is presented in Table 2.

In Exp 2, average daily milk yield of group 1 (nonpregnant) camels decreased slowly from $9.7 \pm 0.32 \mathrm{~kg} / \mathrm{d}$ at $4 \mathrm{wk}$ before mating to $8.3 \pm 0.30 \mathrm{~kg} / \mathrm{d}$ by the ninth week after mating ( $14 \%$ decrease, Figure 5). In group 2 (pregnant) camels, milk yield decreased gradually until the fifth week of gestation, then it dropped from $8.5 \pm$ 0.28 to $5.5 \pm 0.24 \mathrm{~kg} / \mathrm{d}$ by the ninth week $(38 \%$ decrease from the time of conception, Figure 5). Pregnant camels dried off at $123 \pm 13.0 \mathrm{~d}$ of pregnancy. Change point analysis identified a breakpoint in milk yield of pregnant camels (group 2) about 5 wk $(35 \pm 3 \mathrm{~d})$ af-

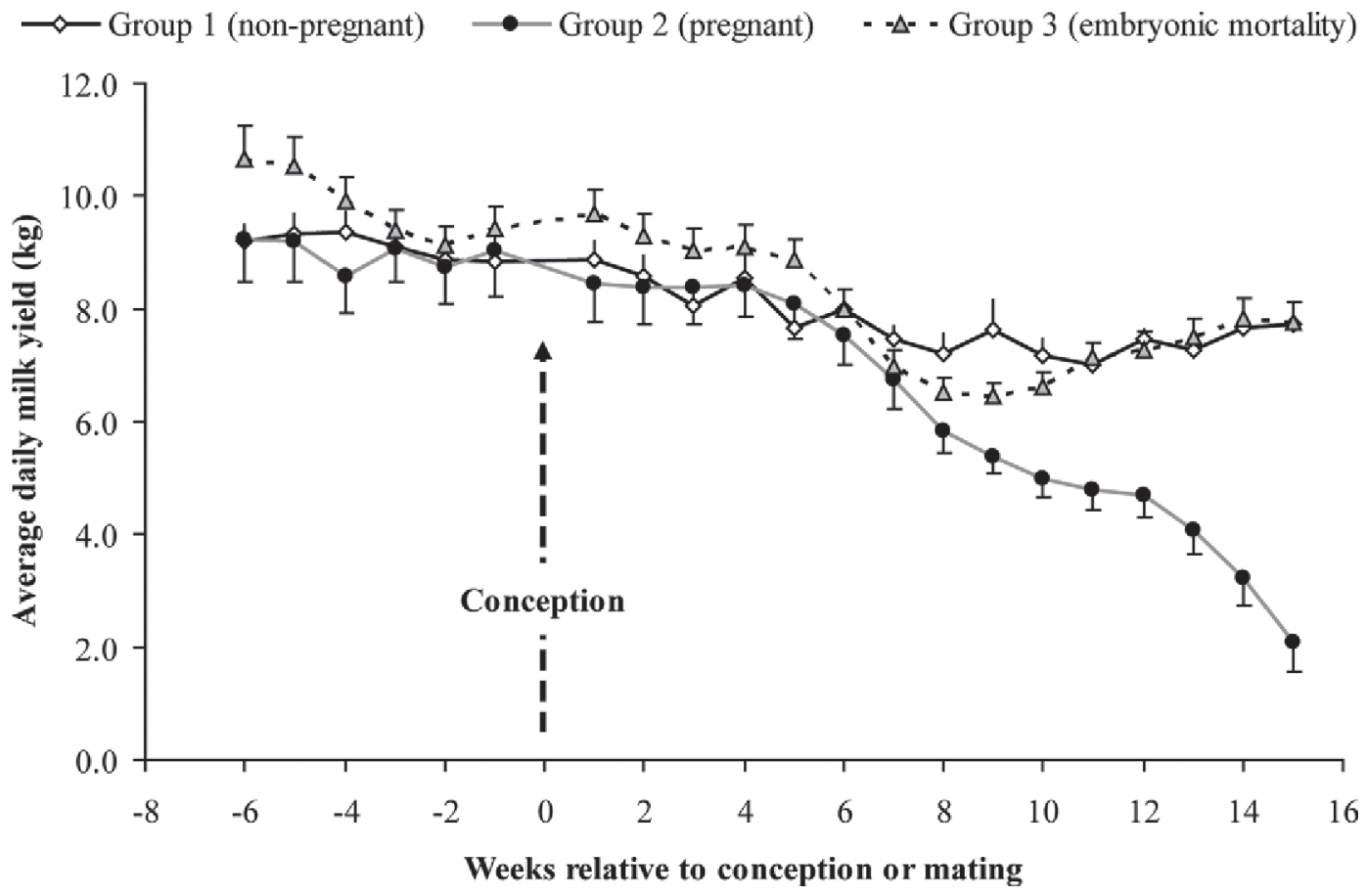

Figure 2. Changes in average daily milk yield in nonpregnant (group $1, \mathrm{n}=4$ ), pregnant (group $2, \mathrm{n}=3$ ), and embryonic mortality (group 3 , $\mathrm{n}=4$ ) camels in experiment 1 . Data are presented relative to the time of conception or first mating (group 1). Doses of PGF $2 \alpha{ }$ were administered to 3 animals on d 62 and 1 camel had spontaneous embryonic mortality on d 60 of gestation. Error bars indicate SEM. 

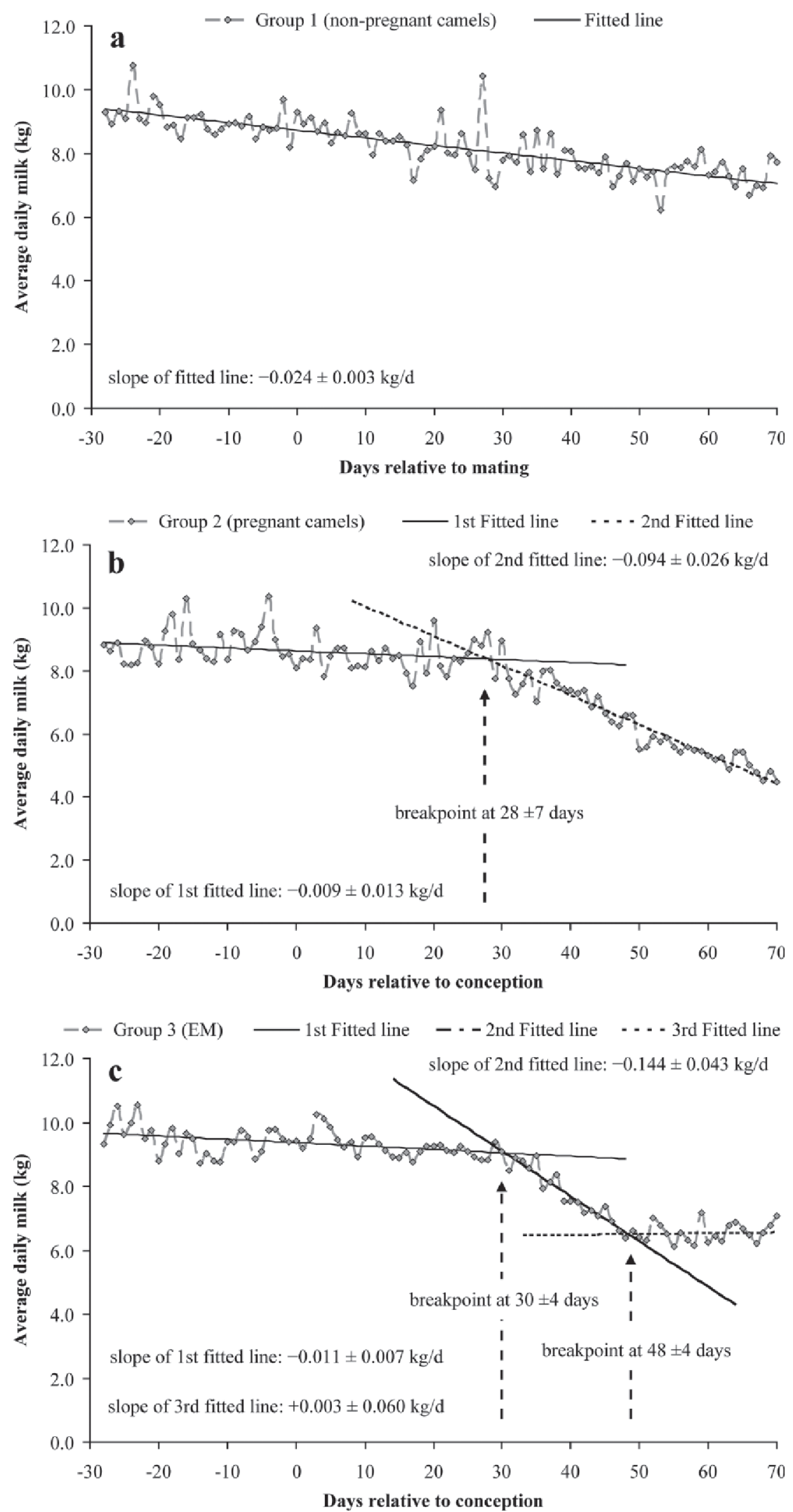

Figure 3. Change point analysis in nonpregnant (group 1, a), pregnant (group 2, b), and embryonic mortality (EM, group 3, c) camels in experiment 1. 
Table 2. Summary of lactation parameters in nonpregnant and pregnant camels in experiment 1 (2009) and 2 (2010)

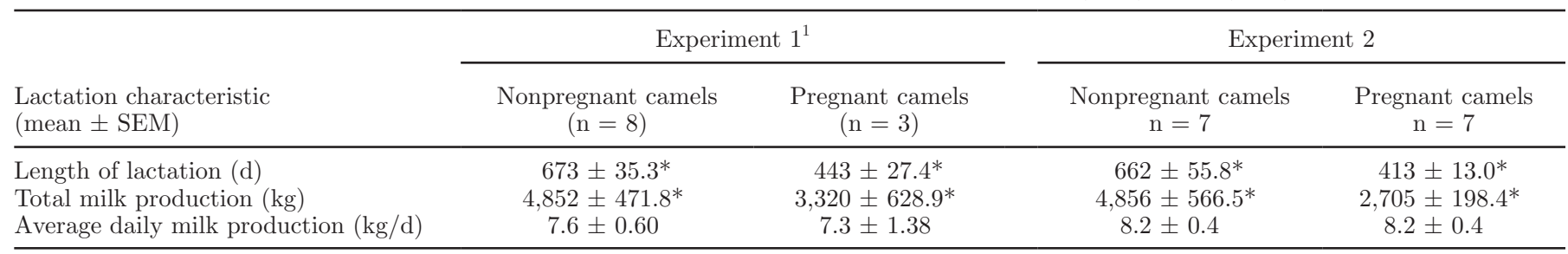

${ }^{1}$ Camels treated with $\mathrm{PGF}_{2 \alpha}$ were considered as nonpregnant for total lactation data.

${ }^{*} P<0.001$.

ter mating. The slope of the lactation curve changed from $-0.014 \pm 0.005$ to $-0.121 \pm 0.014 \mathrm{~kg} / \mathrm{d}(P<$ 0.001, Figure 6b). For nonpregnant camels (group 1), the slope was $-0.012 \pm 0.003 \mathrm{~kg} / \mathrm{d}$ and no significant change point could be identified $(P=0.362$, Figure 6a).

Summary of lactation parameters in Exp 2 is presented in Table 2. Mean length of lactation was shorter by $249 \mathrm{~d}(662$ and $413 \mathrm{~d}, 37.6 \%, P<0.001)$ and mean total lactation production was decreased by $2,151 \mathrm{~kg}$ $(4,856$ and $2,705 \mathrm{~kg}, 44.3 \%, P<0.001)$ in pregnant camels (group 2, $\mathrm{n}=7$ ) compared with nonpregnant animals (group $1, \mathrm{n}=7$, Figure 7 ).

\section{DISCUSSION}

Increasing demand for camel milk highlights the need for intensification of milk production that can be achieved through understanding lactation physiol- ogy in this species. However, such studies are scarce. To improve productivity, it is essential to decrease the calving interval and dry period without affecting total milk production. However, camels are considered to be in lactation anestrus during milking (Tibary and Anouassi, 1997) and field observations made by herdsmen and nomadic people suggest that dromedaries stop lactating shortly after mating. Therefore, it seems that major physiological obstacles exist to short calving intervals in milking camels. This topic has never been addressed scientifically. Our report is the first systematic study evaluating the interaction between pregnancy and lactation in this species.

\section{Reproductive Performance and Serum Progesterone}

Breeding performance in both studies corresponds to our previous findings. All dromedaries showed regular

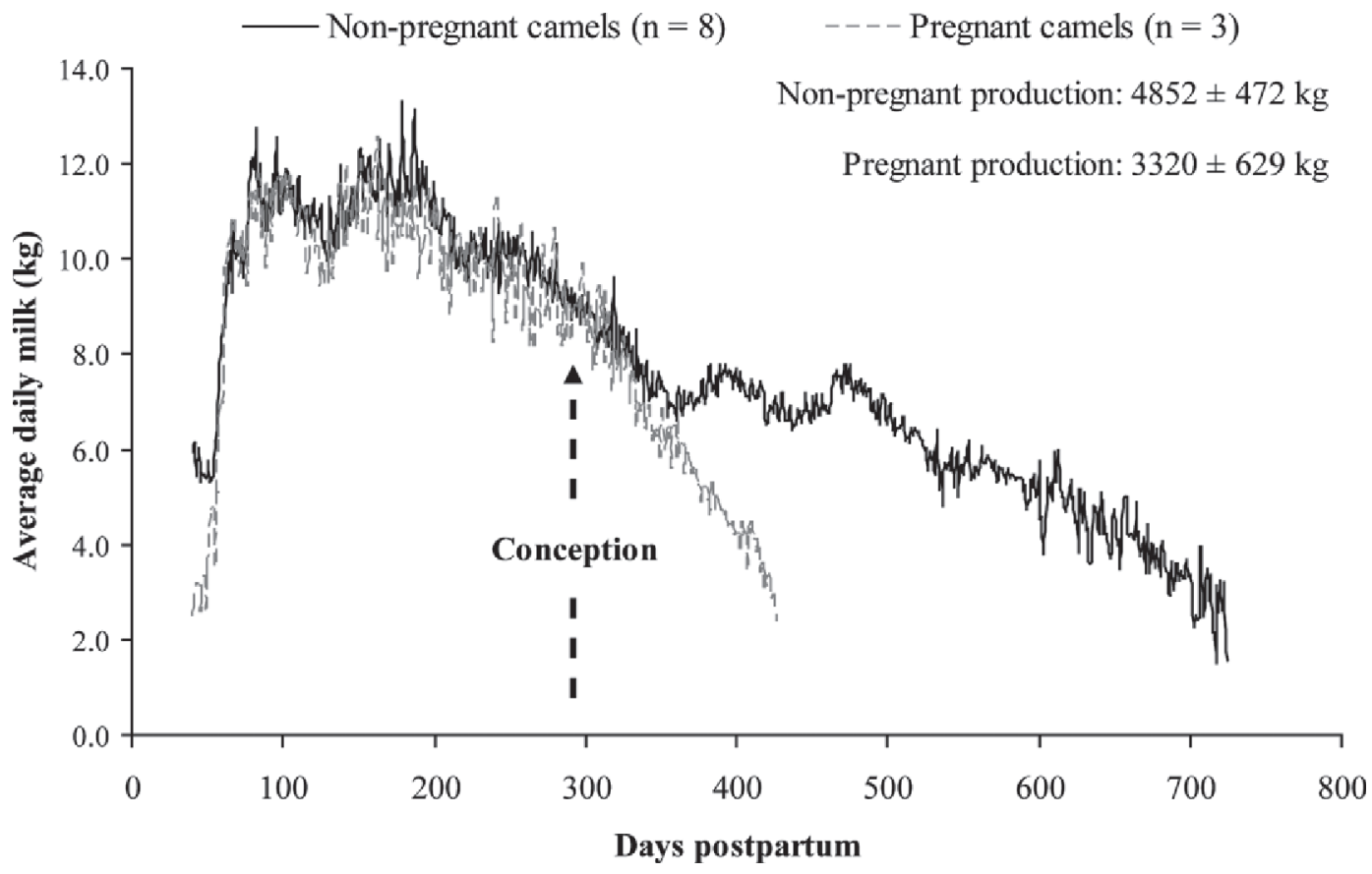

Figure 4. Average daily milk production in nonpregnant (groups 1 and $3, \mathrm{n}=8$ ) and pregnant (group 2, n = 3) camels throughout the lactation in experiment 1. 


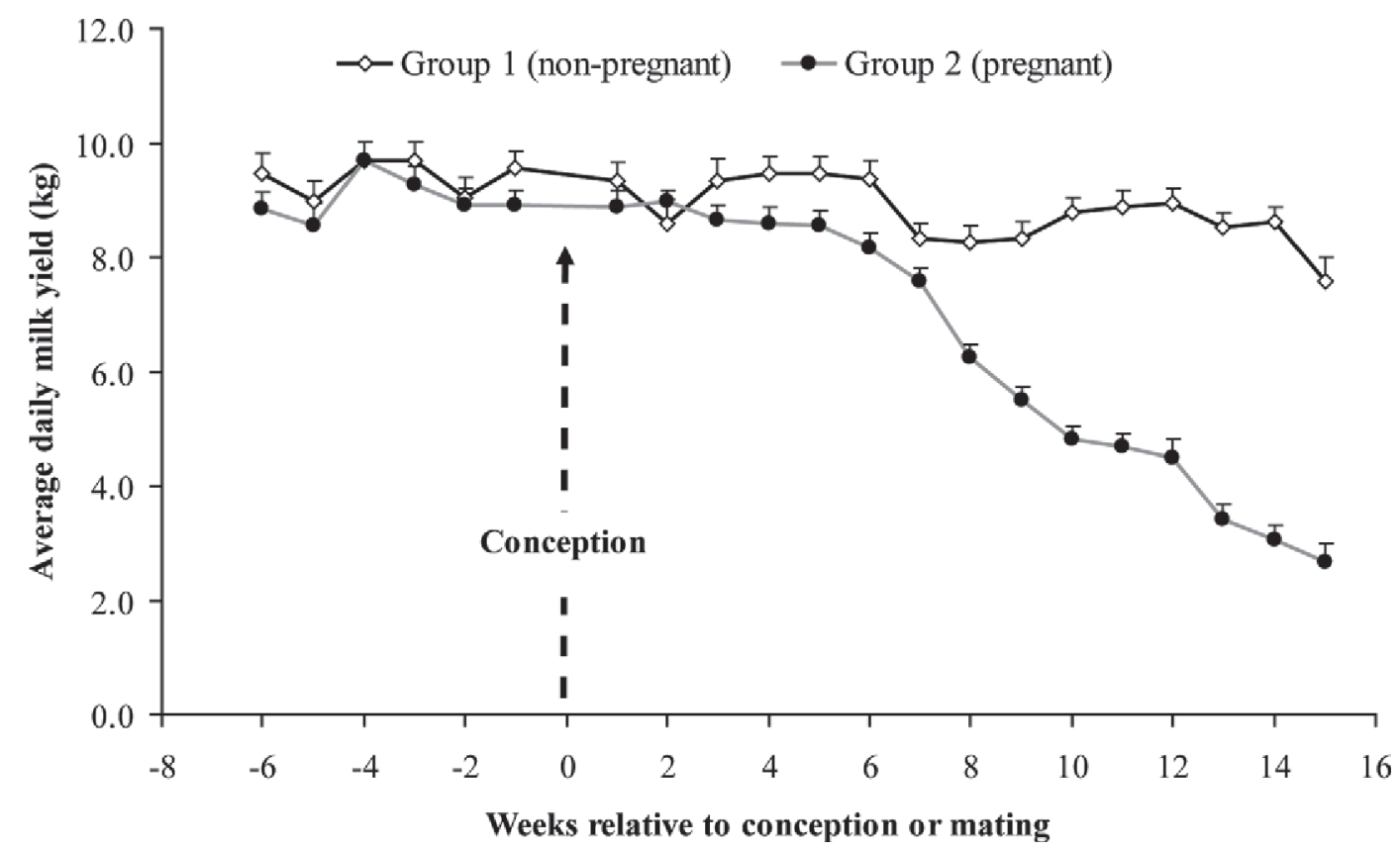

Figure 5. Changes in average daily milk yield in nonpregnant (group $1, \mathrm{n}=7$ ) and pregnant (group $2, \mathrm{n}=7$ ) dromedaries in experiment 2. Data are presented relative to the time of conception or first mating (group 1). Error bars indicate SEM.

follicular activity and controlled natural mating resulted in pregnancy with acceptable per cycle conception rate (36.8-38.1\%). We detected 2 cases of embryonic loss (on d 27 and 60), and 1 camel aborted on d 315 of gestation. These results confirm that dromedaries kept in an intensive system, under good nutrition and reproductive care, have regular follicular growth and are capable of conceiving during midlactation (Nagy et al., 2005; Nagy et al., 2013b). However, the pregnancy rate in our studies was slightly lower compared with earlier reports (40 to 58\%) following natural mating or AI (Abou-Ela, 1994; Skidmore and Billah, 2006; Nagy and Juhasz, 2012). We have no clear explanation why the conception rate in our study seems to be lower compared with previously reported data. The difference could be related to the poorer fertilization rate due to interaction between lactation and fertility. However, this hypothesis is not supported by our observation that fertility of these lactating camels was similar to that of nonlactating females in our herd. Published data on embryonic mortality are scarce in this species, but Tibary et al. (2006) reported that early embryonic loss varies from 8 to $32 \%$. The overall rate of embryonic mortality in these studies was $13.3 \%$ (2 of 15 ). This prevalence corresponds to our earlier finding of $16.1 \%$ including a larger set of data (Nagy and Juhasz, 2012).

Our findings on serum progesterone concentration during the first 60 to $90 \mathrm{~d}$ of gestation are somewhat different from the results of Skidmore et al. (1996).
They reported that mean serum progesterone concentrations began to rise 3 to $4 \mathrm{~d}$ after ovulation and remained constant at 3 to $5 \mathrm{ng} / \mathrm{mL}$ for the first 90 to $100 \mathrm{~d}$ of gestation. In contrast, we found that serum progesterone decreased significantly over time until 90 d of pregnancy (Exp 2). Data on the endocrinology of pregnancy in dromedary camels is limited; therefore, further research is needed, including a larger number of animals to elucidate this difference. As expected, embryonic mortality was characterized by a rapid decline in serum progesterone concentration below $1 \mathrm{ng} / \mathrm{mL}$ within $1 \mathrm{~d}$ after $\mathrm{PGF}_{2 \alpha}$ treatment.

\section{Daily Milk Yield and Total Lactation Production}

As demonstrated, ovarian activity during midlactation is not a limiting factor for decreasing calving interval in this species. The critical question seems to be the length of the dry period. Dromedaries have a long gestation $(>370 \mathrm{~d})$, which means that a short dry period can only be achieved if milk production is maintained during pregnancy.

Milk production of nonpregnant dromedaries decreased slowly over time between the fourth week before and ninth week after mating. This physiological, slow-rate decline in milk yield was observed in both experiments and it corresponds with the slope of the normal lactation curve (Nagy et al., 2013b). We applied a recently described method, the so-called change point 

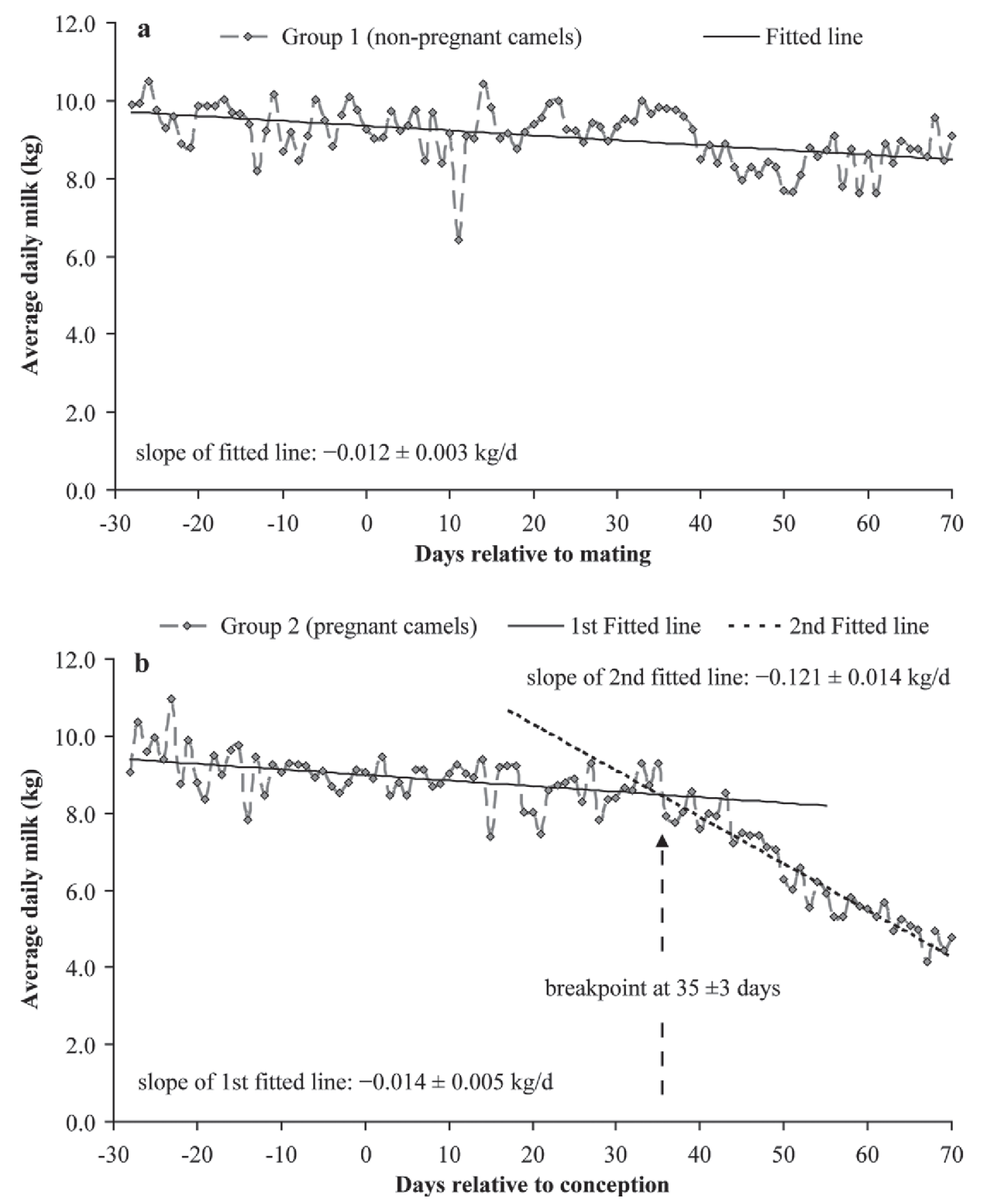

Figure 6. Change point analysis in nonpregnant (group 1, a) and pregnant (group 2, b) dromedaries in experiment 2.

analysis, to demonstrate turning points in the intensity of milk production (Muggeo, 2003). The change point analysis confirmed a continuous and gradual decline in milk yield in nonpregnant animals without any change point. In pregnant camels, the change point model resulted in 1 breakpoint, around 28 to $35 \mathrm{~d}$, after which milk yield dropped sharply. In camels with embryonic mortality, the model identified 2 change points. After the first change point (d 30), a sharp decline in milk yield was observed; but milk production started increasing following the second change point. By searching the best-fitting model, the method was accurate to detect the number of changing points of a curve (Muggeo, 2003). However, we emphasize that the estimated position of a breakpoint does not mirror precisely the time of the biological response. For example, the second breakpoint of the embryonic mortality group (group 3, Exp 1) occurred before the $\mathrm{PGF}_{2 \alpha}$ injection. This de- 


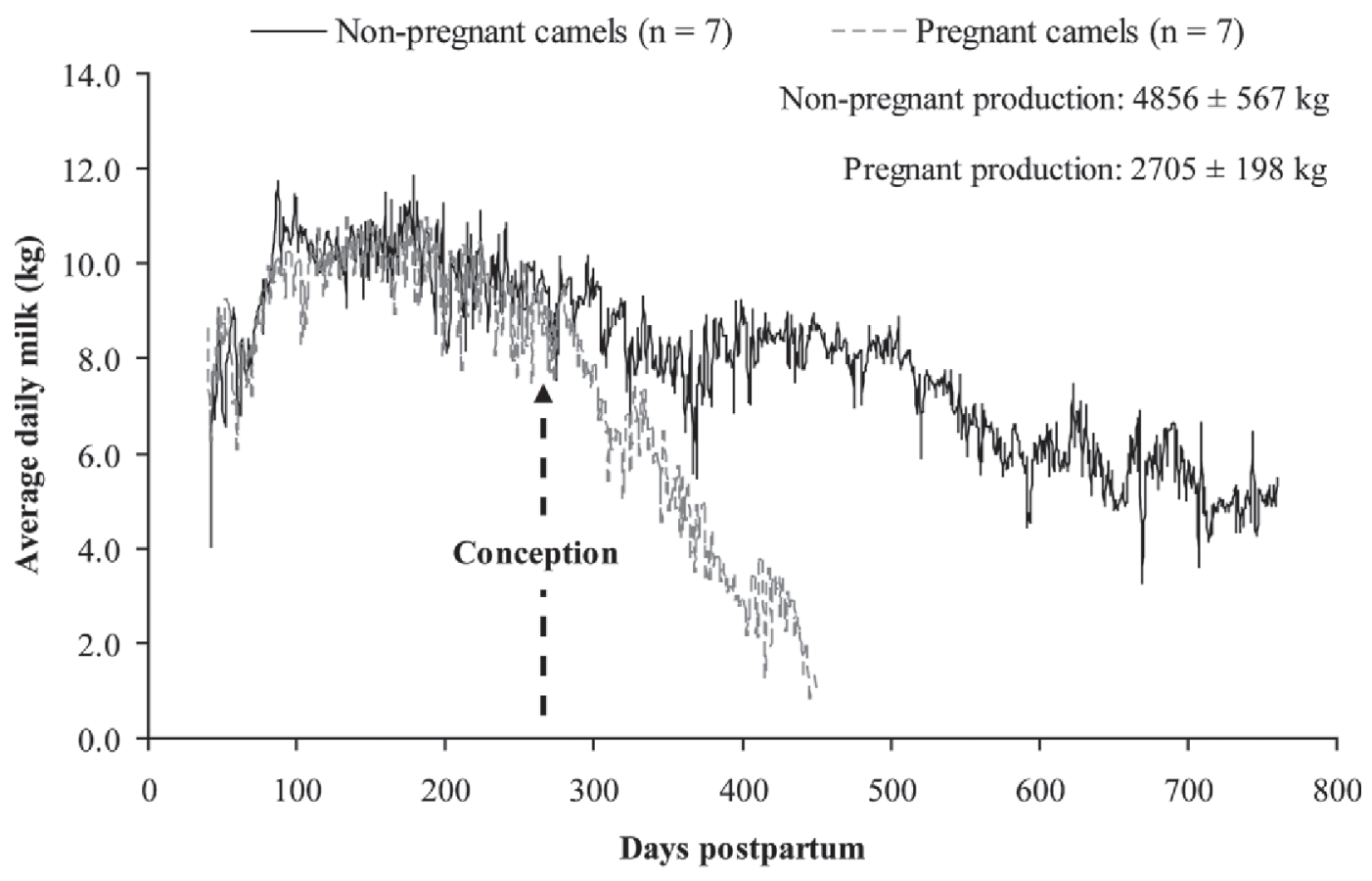

Non-pregnant camels $(n=7) \quad---$ Pregnant camels $(n=7)$

Figure 7. Average daily milk production in nonpregnant (group $1, \mathrm{n}=7$ ) and pregnant (group 2, $\mathrm{n}=7$ ) camels throughout the lactation in experiment 2.

viation could be explained by the fact that the model is fitting straight lines to curves; moreover, we had large individual variation in milk yield due to few animals in the group.

Based on our results, it is obvious that pregnancy has a strong, negative effect on milk production in camels. The same phenomenon was shown earlier in cows (Olori et al., 1997; Bormann et al., 2002), small ruminants (Knight and Wilde, 1988; Salama et al., 2005; Faigl et al. 2011), and buffaloes (Khan et al., 2011, 2012). An important difference seems to exist between species, however. In cows, the negative effect of gestation is marginal and can only be observed in later stage of gestation (Sharma et al., 1990; Roche, 2003). In buffaloes, reduction in milk yield became significant on the seventh to eighth weeks after conception (Khan et al., 2011, 2012). Salama et al. (2005) reported that milk yield of Murciano-Granadina goats declined from wk 10 after conception and dams dried off from wk 14 to 21 of pregnancy. Knight and Wilde (1988) mated Saanen goats at the peak of lactation and found a quick decline in milk yield after the eighth week of pregnancy. Milk production dropped to $57 \%$ of the control value just before parturition.

In Exp 1, we also demonstrated that milk production is restored if embryonic mortality occurs before the fourth month of gestation in dromedary camels.
This is the first report in any domestic mammals that confirms the negative effect of pregnancy on lactation by eliminating its inhibitory action through embryonic mortality.

Although consensus exists about the fact that pregnancy impairs milk yield, the underlying physiological mechanisms are not clearly understood and it seems that there are important differences between species in the regulation of lactogenesis. As no studies are available on milk decline in pregnant dromedaries and on the endocrine control of lactogenesis in camels, we relied on data published for other species.

In general, lactation persistency depends on the number and secretory activity of epithelial cells in the mammary gland. Rates of cell proliferation and cell death determine the net gain or loss of cells and extent of cell renewal within the population (Capuco et al., 2003). A great majority of data dealing with the effect of pregnancy on milk yield derives from dairy cows. However, the described milk loss in dairy cows seems to be less pronounced compared with other species that were not selected for high milk production (Capuco et al., 2003). The negative effect of gestation on milk yield of dairy cows is due to hormonal changes, causing regression of the mammary gland (Akers, 2002), and to nutrient requirements of the fetus which reduces the available nutrients for milk production (Bell et al., 1995). In cows, 
the effect of pregnancy is small at the beginning of gestation and becomes greater at later stages when growth and nutrient requirements of the fetus are increased. In the present experiments, milk yield of dromedaries started declining within $40 \mathrm{~d}$ following conception and camels dried off during the first trimester of pregnancy. At that early stage, the nutrient requirement of fetus is minimal; therefore, this factor cannot be the reason for decreased milk production in pregnant dromedaries.

The regression of the mammary gland in camels is more likely dependent on hormonal changes. Possible candidates in the signaling pathway leading to milk drop during gestation are estrogen, progesterone, prolactin, and IGF-I. In cows, the negative effect of pregnancy on milk yield has been detected as early as d 100 of gestation (Bachman et al., 1988). As this time coincides with the onset of estrogen secretion by the fetal-placental unit, estrogens were implicated as mediators of the inhibitory action of pregnancy on lactation (Bachman et al., 1988; Capuco et al., 2003). Supporting the estrogen theory, administration of estrogen caused mammary gland regression with a significant decline in milk yield in lactating goats (Peaker and Linzell, 1974). Moreover, estradiol injection before drying off accelerated mammary tissue involution in dairy cows (Athie et al., 1997) and goats (Mellado et al., 1998) by promoting plasminogen activation (Athie et al., 1997). In pregnant dromedaries, mean $17 \beta$-estradiol concentration increases only around d 50, then it remains relatively constant from d 90 to 300 (Skidmore et al., 1996). Decrease in milk yield was detected earlier in our experiment, and therefore estrogen is not likely to take part in the downregulation of milk production in pregnant camels.

In the 1970s the effect of estrogen and progesterone on mammogenesis was evaluated extensively in attempts to induce lactation in nonpregnant animals (Akers, 2006). A large number of papers discussed hormonal induction of lactation in cattle based on a variety of short-term injection schemes using estrogen and progesterone. A positive correlation between milk yield following induction and concentration of prolactin was noted. The role of prolactin in lactogenesis was also proven in mares by Guillaume et al. (2003). Those authors induced lactation with a dopamine antagonist following steroid pretreatment in horses. More recently, molecular techniques have proven that prolactin is a primary stimulator of specific promoters for milk protein synthesis (reviewed by Akers, 2006). Progesterone is known to suppress prolactin levels in dogs (Lee at al., 2006) and decreases prolactin release by the pituitary in ovariectomized, estradiol-treated rats (Libertun et al., 1979). It may be hypothesized that increasing progesterone level in dromedaries following conception may lead to milk decline through a negative feedback on pituitary prolactin secretion. As we confirmed in the present study, mean serum progesterone concentration begins to rise 3 to $4 \mathrm{~d}$ after ovulation and remains elevated for the first 90 to $100 \mathrm{~d}$ of gestation (Skidmore et al., 1996).

The other potential candidate in signal transduction is the IGF family, with special attention to IGF-I and its binding proteins. Bovine somatotropin is widely used to maximize milk production in cows (Akers, 2002). Most of its effects are mediated through IGF-I and result in increased proliferation and cell turnover, together with reduced apoptosis in the mammary gland (Capuco et al., 2003). Insulin-like growth factor I also appears to be the most likely mediator of the galactopoietic effect of increased photoperiod in cows (Dahl et al., 2000). In dromedaries, data on the role of IGF-I and IGF binding proteins are scarce. It seems that plasma concentration of IGF-I is increased before conception, but then decreases during the first 2 mo of gestation (Hammadi, 2003). It also needs to be determined whether the growth hormone axis has any role in the regulation of milk production in this species.

Although the physiological background is not clearly understood at present, we found evidence that dromedaries that become pregnant in midlactation dry off within 4 mo of conception. As a result, lactation performance is affected dramatically by pregnancy in this species. Mean length of lactation was shorter by 230 $(34.2 \%)$ and by $249 \mathrm{~d}(37.6 \%)$ and mean total lactation production was decreased by $1,532(31.6 \%)$ and by $2,151 \mathrm{~kg}(44.3 \%)$ in pregnant camels compared with nonpregnant animals in Exp 1 and Exp 2, respectively.

\section{CONCLUSIONS}

We conclude that the calving interval of dromedaries could be decreased by early breeding during midlactation, as follicular wave development was regular and natural mating of lactating camels resulted in an acceptable per-cycle conception rate in our studies. However, pregnancy has a strong negative effect on milk production, as milk yield starts declining within 1 mo of conception and animals stop lactating by $4 \mathrm{mo}$ of gestation. Such a decrease is a major economic loss in a camel dairy operation. We also demonstrated that the negative effect of gestation is reversible if embryonic mortality occurs within 3 mo of conception. As there are few data on the endocrinology of pregnancy and lactation in dromedary camels, further research is essential to understand the underlying mechanisms and optimize the management systems. 


\section{ACKNOWLEDGMENTS}

The authors express their appreciation to the founder and management of Emirates Industries for Camel Milk \& Products (EICMP, Dubai, United Arab Emirates) for their moral and financial support for the research and development in lactating dromedary camels. We also thank EICMP staff for their contribution in milking, handling, and sampling of the animals.

\section{REFERENCES}

Abou-Ela, M. B. 1994. Reproductive performance of the one-hump camel under traditional management in the United Arab Emirates. J. Arid Environ. 26:47-51.

Akers, R. M. 2002. Lactation and the Mammary Gland. 1st ed. Iowa State Press, Ames.

Akers, R. M. 2006. Major advances associated with hormone and growth factor regulation of mammary growth and lactation in dairy cows. J. Dairy Sci. 89:1222-1234.

Al Haj, O. A., and H. A. Al Kanhal. 2010. Compositional, technological and nutritional aspects of dromedary camel milk. Int. Dairy J. 20:811-821.

Athie, F., K. C. Bachman, H. H. Head, M. J. Hayen, and C. J. Wilcox. 1997. Milk plasmin during bovine mammary involution that has been accelerated by estrogen. J. Dairy Sci. 80:1561-1568.

Bachman, K. C., M. J. Hayen, D. Morse, and C. J. Wilcox. 1988. Effect of pregnancy, milk yield, and somatic cell count on bovine milk fat hydrolysis. J. Dairy Sci. 71:925-931.

Bell, A. W., R. Slepetis, and R. A. Ehrhardt. 1995. Growth and accretion of energy and protein in the gravid uterus during late pregnancy in Holstein cows. J. Dairy Sci. 78:1954-1961.

Bormann, J., G. R. Wiggans, T. Druet, and N. Gangler. 2002. Estimating effects of permanent environment, lactation stage, age and pregnancy on test-day yield. J. Dairy Sci. 85:263-267.

Capuco, A. V., S. E. Ellis, S. A. Hale, E. Long, R. A. Erdman, X. Zhao, and M. J. Paape. 2003. Lactation persistency: Insights from mammary cell proliferation studies. J. Anim. Sci. 81:18-31.

Dahl, G. E., B. A. Buchanan, and H. A. Tucker. 2000. Photoperiodic effects on dairy cattle: A review. J. Dairy Sci. 83:885-893.

Faigl, V., M. Keresztes, A. Márton, H. Fébel, K. Kulcsár, S. Nagy, S. Cseh, L. Solti, and G. Huszenicza. 2011. Effect of season and photoperiod on the time of first postpartum ovulation in Awassi ewes. Acta Vet. Hung. 59:497-510. http://dx.doi.org/10.1556/ AVet.2011.036.

Faye, B., and P. Bonnet. 2012. Camel sciences and economy in the world: Current situation and perspectives. Pages $2-15$ in Proc. 3rd Conf. Int. Soc. Camelid Res. Dev. I. Kadim, ed. Sultan Qaboos University Publishing, Muscat, Oman.

Guillaume, D., P. Chavatte-Palmer, Y. Combarnous, G. Duchamp, N. Martinat, P. Nagy, and P. F. Daels. 2003. Induced lactation with a dopamine antagonist in mares: Different responses between ovariectomized and intact mares. Reprod. Domest. Anim. 38:394-400.

Hammadi, M. 2003. Characterisation, nutritional modulation and implication of IGF system in the reproductive function of the female camel (Camelus dromedaries). In French, These de doctorat. Gembloux Agricultural University, Gembloux, France.

Juhasz, J., and P. Nagy. 2012. Development and operation of large scale camel milking farm. Challenges, experiences and results . Hung. Vet. J. 134:52-62. (in Hungarian).

Khan, S., M. S. Qureshi, I. Ahmed, and S. M. Shah. 2011. Milk composition and yield with advancing pregnancy in dairy buffalos (Bubalus bubalis). Turk. J. Vet. Anim. Sci. 35:375-380.

Khan, S., M. S. Qureshi, M. Younas Rafiullah, and M. Inam. 2012. Modeling and management of post-conception decline in milk yield of dairy buffaloes. J. Anim. Plant. Sci. 22(Suppl. 2):5-11.
Knight, C. H., and C. J. Wilde. 1988. Milk production in concurrently pregnant and lactating goats mated out of season. J. Dairy Res. 55:487-493.

Lee, W. M., H. S. Kooistra, J. A. Mol, S. J. Dieleman, and A. C. Schaefers-Okkens. 2006. Ovariectomy during the luteal phase influences secretion of prolactin, growth hormone, and insulin-like growth factor-I in the bitch. Theriogenology 66:484-490.

Libertun, C., S. E. Kaplan, and A. F. De Nicola. 1979. Progesterone negative feedback on prolactin secretion: Importance of the brain control and of estradiol. Neuroendocrinology 28:64-70. http:// dx.doi.org/10.1159/000122845.

Mellado, M., N. Y. Avila, and E. Garcia. 1998. Estrous synchronization with norgestomet and estradiol valerate at the end of lactation accelerates drying off in goats. Small Rumin. Res. 31:61-66.

Muggeo, V. M. R. 2003. Estimating regression models with unknown break-points. Stat. Med. 22:3055-3071.

Nagy, P., B. Faye, O. Marko, S. Thomas, U. Wernery, and J. Juhasz. 2013a. Microbiological quality and somatic cell count in bulk milk of dromedary camels (Camelus dromedarius): descriptive statistics, correlations and factors of variation. J. Dairy Sci. 96:5625-5640. http://dx.doi.org/10.3168/jds.2013-6990.

Nagy, P., and J. Juhasz. 2010. How to decrease calving interval in lactating dromedaries (Camelus dromedarius). Reprod. Domest. Anim. 45(Suppl. 3):100.

Nagy, P., and J. Juhasz. 2012. Fertility after ovarian follicular wave synchronization and fixed-time natural mating compared to random natural mating in dromedary camels (Camelus dromedarius). Anim. Reprod. Sci. 132:223-230.

Nagy, P., J. Juhasz, and U. Wernery. 2005. Incidence of spontaneous ovulation and development of the corpus luteum in non-mated dromedary camels (Camelus dromedarius). Theriogenology 64:292-304.

Nagy, P., S. Thomas, O. Marko, and J. Juhasz. 2013b. Milk production, raw milk quality and fertility of dromedary camels ( Camelus dromedarius) under intensive management. Acta Vet. Hung. 61:71-84. http://dx.doi.org/10.1556/AVet.2012.051.

Olori, V. E., S. Brotherstone, W. G. Hill, and B. J. McGuirk. 1997. Effect of gestation stage on milk yield and composition in Holstein Friesian dairy cattle. Livest. Prod. Sci. 52:167-176.

Peaker, M., and J. L. Linzell. 1974. The effects of oestrus and exogenous oestrogens on milk secretion in the goat. J. Endocrinol. $61: 231-240$.

R Core Team. 2013. R: A language and environment for statistical computing. R Foundation for Statistical Computing, Vienna, Austria. Accessed Nov. 6, 2014. http://www.R-project.org/.

Roche, J. R. 2003. Effect of pregnancy on milk production and body weight from identical twin study. J. Dairy Sci. 86:777-783.

Salama, A. A. K., G. Caja, X. Such, R. Casals, and E. Albanell. 2005. Effect of pregnancy and extended lactation on milk production in dairy goats milked once a day. J. Dairy Sci. 88:3894-3904.

Sharma, A. K., C. J. Wilcox, F. G. Martin, and W. W. Thatcher. 1990. Effects of stage of lactation and pregnancy and their interaction on milk yield and constituent. J. Dairy Sci. 73:1586-1592.

Skidmore, J. A., and M. Billah. 2006. Comparison of pregnancy rates in dromedary camels (Camelus dromedarius) after deep intra-uterine versus cervical insemination. Theriogenology 66:292-296.

Skidmore, J. A., M. Billah, and W. R. Allen. 1996. Patterns of hormone secretion throughout pregnancy in the one-humped camel (Camelus dromedarius). Reprod. Fertil. Dev. 8:863-869.

Tibary, A., and A. Anouassi. 1997. Reproductive management of Camelidae. Pages 459-479 in Theriogenology in Camelidae. Actes Éditions,, Institute Agronomique et Veterinaire Hassan I, Rabat, Morocco.

Tibary, A., C. Fite, A. Anouassi, and A. Sghiri. 2006. Infectious causes of reproductive loss in camelids. Theriogenology 66:633-647. 